\title{
Correction to: Influences of Wave Climate and Sea Level on Shoreline Erosion Rates in the Maryland Chesapeake Bay
}

\author{
Lawrence P. Sanford $^{1}$. Jia Gao ${ }^{1}$
}

Published online: 7 January 2019

(C) The Author(s) 2019

\section{Correction to: Estuaries and Coasts (2018) 41 (Suppl 1): S19-S37 https://doi.org/10.1007/s12237-017-0257-7}

The article Influences of Wave Climate and Sea Level on Shoreline Erosion Rates in the Maryland Chesapeake Bay, written by Lawrence P. Sanford and Jia Gao, was originally published electronically on the publisher's internet portal (currently SpringerLink) on 22 May 2017 without open access.

With the author(s)' decision to opt for Open Choice the copyright of the article changed January 2019 to (C) The Author(s) 2019 and the article is forthwith distributed under the terms of the Creative Commons Attribution 4.0 International License (http://creativecommons.org/licenses/by/ 4.0/), which permits use, duplication, adaptation, distribution and reproduction in any medium or format, as long as you give appropriate credit to the original author(s) and the source, provide a link to the Creative Commons license and indicate if changes were made.

The original article has been corrected.

Open Access This article is distributed under the terms of the Creative Commons Attribution 4.0 International License (http:// creativecommons.org/licenses/by/4.0/), which permits use, duplication, adaptation, distribution and reproduction in any medium or format, as long as you give appropriate credit to the original author(s) and the source, provide a link to the Creative Commons license and indicate if changes were made.

The online version of the original article can be found at https://doi.org/ $10.1007 / \mathrm{s} 12237-017-0257-7$

Lawrence P. Sanford

1sanford@umces.edu

1 Horn Point Laboratory, University of Maryland Center for Environmental Science, PO Box 775, Cambridge, MD 21613, USA 